\title{
EFIKASI PESTISIDA NABATI MINYAK KEMIRI SUNAN (Reutealis trisperma (Blanco) Airy Shaw) UNTUK MENGENDALIKAN HAMA PENGGEREK BUAH KOPI (Hypothenemus hampei Ferrari)
}

\section{THE EFFICACY OF BIOPESTICIDIES OF KEMIRI SUNAN OIL (Reutealis trisperma (Blanco) Airy Shaw) IN CONTROLLING BARRY BORER (Hypothenemus hampei Ferrari)}

\author{
Euis Rahmawati ${ }^{1}$, Ida Hodiyah ${ }^{1}$, Fittri Kurniati ${ }^{1}$, Gusti Indriati ${ }^{2}$ \\ ${ }^{1}$ Program Studi Agroteknologi Fakultas Pertanian Universitas Siliwangi \\ ${ }^{2}$ Balai Penelitian Tanaman Industri dan Penyegar
}

Korespondensi : euis.rahma22@gmail.com

\begin{abstract}
ABSTRAK
Penggerek buah kopi (PBKo), Hypothenemus hampei merupakan salah satu hama utama pada tanaman kopi yang perkembangbiakannya terjadi di dalam buah kopi. Serangan hama ini dapat menyebabkan kerugian yang cukup besar. Minyak kemiri sunan mengandung senyawa metabolit sekunder berupa senyawa alkaloid, saponin, fenolik, flavonoid, tritervenoid, dan glikosida. Penelitian ini bertujuan untuk mengetahui efikasi pestisida nabati minyak kemiri sunan untuk mengendalikan hama penggerek buah kopi. Penelitian dilaksanakan pada Mei sampai dengan Juli 2019 di Laboratorium Proteksi Tanaman Balai Penelitian Tanaman Industri dan Penyegar (Balittri) Sukabumi. Penelitian menggunakan Rancangan Acak Lengkap (RAL) yang terdiri dari tujuh perlakuan dan diulang sebanyak empat kali, yaitu $\mathrm{p}_{0}, \mathrm{p}_{1}, \mathrm{p}_{2}, \mathrm{p}_{3}, \mathrm{p}_{4}, \mathrm{p}_{5}$ dan $\mathrm{p}_{6}$. Data dianalisa menggunakan sidik ragam dengan uji $\mathrm{F}$ dan dilanjutkan dengan Uji Jarak Berganda Duncan dengan taraf nyata 5\%. Hasil penelitian menunjukkan konsentrasi minyak kemiri sunan $8 \%$ merupakan konsentrasi paling efektif dalam mengendalikan hama penggerek buah kopi (PBKo) Hypothenemus hampei Ferr.
\end{abstract}

Kata kunci : Kemiri sunan, Kopi, PBKo

\begin{abstract}
Hypothenemus hampei is one of the main pests in coffee plant whose propagation occurs in the fruit. This pest attack can cause substantial losses. Kemiri sunan oil contains secondary metabolite compounds in the form of alkaloid, saponin, phenolic, flavonoid, tritervenoid, and glycoside compounds. This research aim to determine the efficacy of kediri suntan oil as biopesticides to controlling the berry borer in coffee. The experiment was conducted from May until July 2019 at the Plant Protection Laboratory of the Indonesian Agency For Agricultural Research And Development Ministry Of Agriculture (Balittri) Sukabumi. This research use a completely randomized design consisting of seven treatments and repeated four times, that is $\mathrm{p} 0=$ control, $\mathrm{p} 1=$ $5,2 \%, \mathrm{p} 2=6 \%, \mathrm{p} 38 \%, \mathrm{p} 4=10 \%, \mathrm{p} 5=12 \%, \mathrm{p} 6=$ Dufon prevathon $0,1 \%$. Data was analyzed using variance with the F test and continued with Duncan's Multiple Distance Test with a real level of
\end{abstract}


$5 \%$. The result indicated that the concentration of $8 \%$ was the most effective in controlling the barry borer (Hypothenemus hampei).

Keywords : Berry borer, Coffee, Reutealis trisperma

\section{PENDAHULUAN}

Kopi (Coffea sp.) merupakan salah satu komoditas perkebunan yang memiliki nilai ekonomi tinggi, sebagai penghasil devisa negara, serta salah satu jenis tanaman yang mendapatkan banyak perhatian dalam pengembangannya karena mempunyai prospek yang baik dalam permintaan pasar komoditas, juga sebagai bahan ekspor utama negara Indonesia.

Permintaan pasar dunia menghendaki produk kopi yang bermutu dan berkualitas baik, sehingga dalam budidayanya harus diperhatikan, terutama faktor-faktor penghambat seperti faktor lingkungan yang tidak sesuai, sistem pemeliharan yang belum optimal, lahan perkebunan yang kurang memadai, penanganan panen dan pasca panen serta gangguan hama dan penyakit tanaman.

Organisme pengganggu tanaman merupakan salah satu faktor yang menjadi masalah utama karena dapat menurunkan produktivitas dan kualitas dari tanaman kopi, seperti biji kopi berlubang, dan buah muda yang gugur.

Produksi kopi di Indonesia terus mengalami penurunan, yaitu dari 698.016 ton pada tahun 2008 menjadi 685.089 ton pada tahun 2014 (Ditjenbun, 2014). Jika hama PBKo dibiarkan terus menerus maka akan memberikan dampak yang sangat buruk, selain itu juga dapat menurunkan kualitas biji yang dihasilkan.

Upaya dalam pengendalian PBKo masih bertumpu pada penggunaan pestisida sintetik, namun seiring dengan kemajuan zaman dan perkembangan ilmu pengetahuan dan teknologi, gaya hidup yang menuntut untuk back to nature, serta kesadaran akan bahaya residu racun pada produk kopi, maka tuntutan akan teknologi pengendali OPT yang ramah lingkungan meningkat, salah satu usaha untuk mengatasi masalah tersebut yaitu dengan memanfaatkan bahan alami sebagai pestisida nabati yang lebih selektif dan ramah lingkungan.

Salah satu tanaman yang dapat digunakan sebagai pestisida nabati yaitu kemiri sunan (Reutealis trisperma (Blanco) Airy Shaw) yang merupakan tanaman perkebunan penghasil minyak. Minyak kemiri sunan mengandung zat kimia berupa saponin, alkaloid, flavonoid, fenolik, triterpenoid, dan glikosida (Susanthy dan Samsudin 2014). Daging biji atau kernel kemiri sunan apabila diesktrak akan menghasilkan minyak kasar dengan rendemen 45-50\%, dan di dalam minyak kasar kemiri sunan mengandung 50\% asam $\alpha$-oleostearat yang bersifat racun (Vosen dan Umali, 2002 dalam Herman dkk., 2013) sehingga berpotensi sebagai pestisida nabati.

Adanya zat racun yang terkandung dalam hampir seluruh bagian tanaman kemiri sunan menyebabkan tanaman kemiri sunan jarang diserang hama maupun ternak (Puslitbang Pertanian, 2012).

Pemanfaatan tanaman kemiri sunan sebagai bahan pestisida nabati sangat layak untuk dikembangkan karena selain mengandung zat racun juga sangat potensial untuk dibudidayakan pada lahan-lahan kritis 
atau lahan marjinal, juga dapat dijadikan sebagai tanaman konservasi.

Berdasarkan uraian tersebut, penulis bertujuan untuk melakukan penelitian tentang efikasi pestisida nabati minyak kemiri sunan (Reutealis trisperma (Blanco) Airy Shaw) untuk mengendalikan hama penggerek buah kopi (Hypothenemus hampei Ferr.)

\section{BAHAN DAN METODE}

Percobaan dilakukan di Balai Penelitian Tanaman Industri dan Penyegar (Balittri), Jalan Raya Pakuwon Parungkuda Km.2 Kabupaten Sukabumi. Penelitian dilakukan pada bulan Mei sampai dengan bulan Juli 2019

Bahan-bahan yang digunakan pada percobaan ini adalah imago hama PBKo Hypothenemus hampei, buah kopi, aquades, detergen, dan minyak kemiri sunan. Alat-alat yang digunakan pada penelitian ini adalah petridish, toples, sprayer, koas, cutter, wadah plastik, gelas ukur, batang pengaduk, saringan, gunting, timbangan analitik, kain tile, karet, pipet elektrik, mikroskop, alat tulis dan kamera.

Percobaan menggunakan Rancangan Acak Lengkap (RAL) dengan perlakuan berbagai knsentrasi minyak kemiri sunan yang diaplikasikan pada buah kopi, dan diulang sebanyak empat kali. Perlakuan konsntrasi yang dicoba adalah: $\mathrm{p}_{0}$ (kontrol $\left.0 \%\right), \mathrm{p}_{1}$ (kemiri sunan 5,2\%), $\mathrm{p}_{2}$ (kemiri sunan 6\%), $\mathrm{p}_{3}$ (kemiri sunan 8\%), $\mathrm{p}_{4}$ (kemiri sunan $10 \%$ ), $\mathrm{p}_{5}$ (kemiri sunan 12\%) $\mathrm{p}_{6}$ (Dufon prevathon $0,1 \%$ ). Konsentrasi minyak kemiri sunan yang diuji ditentukan berdasaran hasil analisi probit LC50 minyak kemiri sunan yaitu 5,2\%, kemudian dijadikan sebagai acuan konsentrasi minyak kemiri sunan dalam uji lanjutan.
Imago PBKo diperoleh dari buah-buah kopi yang terserang di kebun percobaan balittri, PBKo tersebut dipelihara di dalam toples yang ditutup menggunakkan kain tile dan diikat menggunakan karet, dalam satu buah yang terserang rata-rata ditemukan 5-10 ekor imago PBKo.

Buah kopi yang digunakan pada percobaan ini jenis kopi Arabika, yang berasal dari kebun percobaan Balittri yaitu buah yang sudah berwarna merah atau warna merah kekuningan, atau merupakan buah kopi yang sudah matang.

Minyak kemiri sunan yang digunakan dalam percobaan ini diperoleh dari Balittri yang telah disediakan. Minyak kemiri sunan tersebut (konsentrasi 5,2\%, 6\%, 8\%, 10\% dan $12 \%$ dilarutkan menggunakan pelarut aquades sampai volume larutan mencapai 25 $\mathrm{ml}$ dan ditambahkan $0,5 \mathrm{~g}$ detergen yang berfugsi sebagai perekat dan pengemulsi (Irfan, 2016). Perlakuan yang diberikan yaitu dengan cara menyemprotkan larutan pestisida nabati minyak kemiri sunan $(25 \mathrm{ml})$ yang telah dibuat sesuai dengan konsentrasi yang telah ditentukan, dengan volume semprot masing-masing $6,25 \mathrm{ml} /$ petridish terhadap seuruh buah pada setiap perlakuan, dalam satu petridish terdapat 20 buah kopi. Adapun alat yang digunakan merupakan sprayer kecil dengan kapasitas $10 \mathrm{ml}$.

Parameter yang diamati yaitu : mortalitas imago PBKo, intensitas serangan, dan kecepatan kematian, data dianalisis berdasaran ANOVA kemudian Uji DUNCAN pada taraf nyata $5 \%$.

\section{HASIL DAN PEMBAHASAN}

Pengamatan yang dilakukan meliputi pengamatan terhadap mortalitas imago PBKo, intensitas serangan, dan kecepatan kematian. 
Mortalitas imago PBKo

Tabel 1. Pengaruh konsentrasi minya kemiri sunan terhadap persentase mortalitas imago penggerek buah kopi Hypothenemus hampei

\begin{tabular}{|c|c|c|c|c|c|c|c|}
\hline \multirow{2}{*}{$\begin{array}{l}\text { Konsentrasi minyak } \\
\text { kemiri sunan }\end{array}$} & \multicolumn{7}{|c|}{ Mortalitas imago PBKo (\%) pada pengamatan } \\
\hline & 3 jam & 6 jam & 24 jam & 48 jam & $72 \mathrm{jam}$ & 96 jam & 120 jam \\
\hline $0 \%$ & 5 & $5 \mathrm{a}$ & $5 \mathrm{a}$ & $5 \mathrm{a}$ & $5 \mathrm{a}$ & $5 \mathrm{a}$ & $5 \mathrm{a}$ \\
\hline $5,2 \%$ & $20 \mathrm{~b}$ & $35 \mathrm{~b}$ & $43 \mathrm{bc}$ & $45 \mathrm{~b}$ & $45 \mathrm{~b}$ & $45 \mathrm{~b}$ & $45 \mathrm{~b}$ \\
\hline $6 \%$ & $40 \mathrm{bc}$ & $45 \mathrm{bc}$ & $48 \mathrm{c}$ & $48 \mathrm{~b}$ & $48 \mathrm{~b}$ & $48 \mathrm{~b}$ & $48 \mathrm{~b}$ \\
\hline $8 \%$ & $55 \mathrm{~cd}$ & $68 \mathrm{~cd}$ & $88 \mathrm{~d}$ & $93 \mathrm{c}$ & $93 \mathrm{c}$ & $93 \mathrm{c}$ & $93 \mathrm{c}$ \\
\hline $10 \%$ & $67,5 \mathrm{~d}$ & $88 \mathrm{de}$ & $98 \mathrm{~d}$ & $98 \mathrm{c}$ & $98 \mathrm{c}$ & $98 \mathrm{c}$ & $98 \mathrm{c}$ \\
\hline $12 \%$ & $87,5 \mathrm{e}$ & $95 \mathrm{e}$ & $98 \mathrm{~d}$ & $98 \mathrm{c}$ & $98 \mathrm{c}$ & $98 \mathrm{c}$ & $98 \mathrm{c}$ \\
\hline Dufon Prevathon & & & & & & & \\
\hline $0,1 \%$ & 0 & $0 \quad \mathrm{a}$ & $23 a b$ & $35 \mathrm{~b}$ & $38 \mathrm{~b}$ & $40 \mathrm{~b}$ & $43 \mathrm{~b}$ \\
\hline
\end{tabular}

Keterangan : Angka-angka yang ditandai dengan huruf yang sama pada kolom yang sama tidak berbeda nyata menurut Uji Jarak Berganda Duncan pada taraf 5\%.

Hasil analisis statistik menunjukkan bahwa perlakuan konsentrasi pestisida nabati minyak kemiri sunan berpengaruh nyata terhadap mortalitas imago PBKo. Persentase mortalitas imago PBKo pada perlakuan minyak kemiri sunan dengan konsentrasi $10 \%$ dan $12 \%$ menunjukkan persentase terbesar yaitu $98 \%$, sedangkan persentase terendah diperoleh dari konsentrasi $0 \%$ yaitu $5 \%$.

Mortalitas pada imago PBKo disebabkan karena pestisida nabati minyak kemiri sunan mengandung senyawa metabolit sekunder yang bersifat racun bagi serangga, metabolit sekunder sendiri ialah senyawa organik yang berukuran lebih kecil dan diproduksi dalam sel tumbuhan dengan jumlah yang sangat terbatas, memiliki fungsi sebagai pelindung tanaman dari gangguan serangga, bakteri, cendawan, jamur dan patogen (Muta'ali dan Purwani, 2015).

Senyawa metabolit sekunder yang terdapat di dalam tanaman kemiri sunan yaitu, alkaloid, saponin, fenolik, flavonoid, triterpenoid, dan glikosida, bersifat sebagai antifeedan dan beracun sehingga dapat menyebabkan kematian serangga. Serta adanya kandungan senyawa $\alpha$-eleostrearat. Syafarudin dan Santoso (2011) menyatakan bahwa minyak kemiri sunan mengandung $50 \%$ senyawa asam $\alpha$-eleostrearat dan senyawa tersebut sangat beracun.

Rasa pahit yang terkandung di dalam senyawa alkaloid dan saponin dapat mempengaruhi perilaku makan serangga, sehinga hama penggerek buah kopi tidak menggerek buah kopi. Selain rasa pahit dari bahan aktif saponin juga dapat menyebabkan kematian serangga karena bersifat racun syaraf. Hal ini sesuai dengan pernyataan Kinasih (2013) bahwa saponin berpengaruh terhadap mortalitas serangga dengan cara merusak sel-sel syaraf yang dapat menyebabkan menurunnya nafsu makan dan akhirnya tubuh serangga melemah.

Senyawa alkaloid bekerja efektif sebagai racun kontak apabila bersentuhan langsung dengan tubuh serangga. Hal ini sesuai dengan pernyataan Kaihena dkk, (2011) bahwa bagian terluar tubuh serangga dapat menyerap zat toksik dalam jumlah yang besar, zat toksik tersebut mampu berdifusi dari lapisan kutikula terluar menuju lapisan yang paling dalam menuju hemolimfa, kemudian menyebar ke seluruh bagian tubuh serangga dan dapat menyebabkan kematian serangga. 
Konsentrasi pestisida nabati minyak kemiri sunan $8 \%$ lebih efektif dalam menyebabkan mortalitas imago penggerek buah kopi, karena hasilnya setara dengan mortalitas pada konsentrasi tertinggi yaitu $12 \%$.

Persentase mortalitas imago PBKo konsentrasi minyak kemiri sunan $0 \%$ pada waktu 3 JSA sebesar $5 \%$ dan tidak mengalami kenaikkan sampai dengan akhir pengamatan 120 JSA, pada konsentrasi minyak kemiri sunan 5,2\% mortalitas imago PBKo pada waktu 3 JSA sebesar 20\% kemudian meningkat sampai pada waktu 48 JSA yaitu sebesar $45 \%$, pada konsentrasi minyak kemiri sunan 6\% mortalitas imago PBKo pada 3 JSA sebesar $40 \%$ kemudian meningkat sampai pada waktu 24 JSA yaitu sebesar $48 \%$, pada konsentrasi minyak kemiri sunan $8 \%$ mortalitas imago PBKo pada 3 JSA sebesar 55\% kemudian meningkat sampai pada waktu 48 JSA yaitu sebesar 93\%, sedangkan pada konsentrasi minyak kemiri sunan $10 \%$ dan $12 \%$ persentase mortalitas pada waktu 3 JSA mencapai $67,5 \%$ dan $87,5 \%$, kemudian meningkat sampai dengan 98\% pada waktu 24 JSA. Pada konsentrasi Dufon prevathon $0,1 \%$ persentase mortalitas imago PBKo 3 JSA sampai 6 JSA 0\%, kemudian meningkat pada 24 JSA sebesar $23 \%$ sampai pada waktu 120 JSA sebesar $43 \%$.

pestisida nabati minyak kemiri sunan dengan konsentrasi tertinggi $12 \%$ menyebabkan mortalitas imago PBKo yang lebih banyak, karena kandungan bahan aktif pada konsentrasi yang tinggi jumlahnya lebih banyak, serta waktu yang diperluan lebih sedikit untuk dapat mematikan imago PBKo, karena daya toksik yang lebih banyak.

\section{Intensitas serangan}

Intensitas serangan merupakan parameter pengamatan yang menggambarkan jumlah buah kopi yang terserang imago PBKo yang ditandai dengan adanya lubang bekas gerekan pada buah kopi.

Tabel 2. Pengaruh konsentrasi minyak kemiri sunan terhadap intensitas serangan PBKo pada 3 JSA sampai dengan 120 JSA.

\begin{tabular}{|c|c|}
\hline Konsentrasi minyak kemiri sunan & Intensitas serangan $(\%)$ \\
\hline $0 \%$ & $43,8 \% \quad c$ \\
\hline $5,2 \%$ & $10,0 \% \mathrm{ab}$ \\
\hline $6 \%$ & $10,0 \% \mathrm{ab}$ \\
\hline $8 \%$ & $2,5 \%$ \\
\hline $10 \%$ & $2,5 \%$ \\
\hline $12 \%$ & $2,5 \%$ \\
\hline Dufon Prevathon $0,1 \%$ & $13,8 \% \quad b$ \\
\hline
\end{tabular}

Keterangan : Angka-angka yang ditandai dengan huruf yang sama pada kolom yang sama tidak berbeda nyata menurut Uji Jarak Berganda Duncan pada taraf 5\%

Hasil analisis statistik menunjukan bahwa perlakuan pestisida nabati minyak kemiri sunan berpengaruh nyata terhadap intensitas serangan hama penggerek buah kopi.
Berbagai konsentrasi pestisida nabati minyak kemiri sunan dapat menekan intensitas serangan hama penggerek buah kopi lebih tinggi dibandingan dengan perlakuan kontrol 
dan juga pestisida sintetik Dufon Prevvathon $0,1 \%$. Hal ini disebabkan karena imago penggerek buah kopi (PBKo) mengalami penurunan aktivitas dalam menyerang buah kopi. Penurunan aktivitas disebabkan oleh adanya senyawa antifeedan seperti flavonoid, triterpenid, dan fenolik dalam pestisida nabati minyak kemiri sunan. Wulanda dkk, (2017) menyatakan bahwa zat alkaloid, terpenoid, fenolik, tanin dan zat-zat kimia lainnya berpengaruh terhadap perilaku serangga seperti penolak serangga, anti makan (antifeedan). Serta racun kontak senyawa alkaloid yang menyebabkan penggerek buah kopi mati sebelum menyerang atau sebelum dapat menggerek buah kopi.
Pestisida nabati minyak kemiri sunan cukup efektif menekan intensitas serangan hama PBKo pada konsentrasi 8\%, karena pada onsentrasi tersebut berbeda tidak nyata dengan konsentrasi $12 \%$.

\section{Kecepatan Kematian}

Kecepatan kematian merupakan parameter pengamatan yang menggambarkan jumlah hama yang mati dalam satuan waktu tertentu. Berdasarkan hasil analisis statistik menunjukkan bahwa penggunaan minyak kemiri sunan berpengaruh nyata terhadap kecepatan kematian imago PBKo.

Tabel 3. Pengaruh konsentrasi minyak kemiri sunan terhadap kecepatan kematian imago PBKo pada 3 JSA sampai dengan 120 JSA

\begin{tabular}{cc}
\hline Konsentrasi minyak kemiri sunan & Rata-rata kecepatan kematian (ekor/jam) \\
\hline $0 \%$ & $0,35 \mathrm{a}$ \\
$5,2 \%$ & $2,8 \mathrm{bc}$ \\
$6 \%$ & $3,2 \mathrm{c}$ \\
$8 \%$ & $5,8 \mathrm{~d}$ \\
$10 \%$ & $6,4 \mathrm{~d}$ \\
$12 \%$ & $6,7 \mathrm{~d}$ \\
& $1,8 \mathrm{~b}$ \\
\hline Keterangan : & Angka-angka yamg ditandai dengan huruf yang sama tidak berbeda nyata menurut Uji Jarak Berganda
\end{tabular}

Konsentrasi yang lebih efektif adalah konsentrasi $8 \%$, dengan jumlah kecepatan kematian 5,8 ekor/jam, kecepatan tertinggi diperoleh dari perlakuan minyak kemiri sunan dengan konsentrasi $12 \%$ yaitu 6,7 ekor/jam, sedangkan kecepatan kematian terendah diperoleh dari kontrol yaitu 0,35 ekor/jam.

Hal ini disebabkan karena semakin tinggi konsentrasi yang diberikan maka kandungan bahan aktif dalam pestisida juga semakin banyak, sehingga daya racun semakin tinggi dan proses kematian hama akan semakin cepat. Hal ini sejalan dengan pernyataan Sonia, Siswancipto, dan Febrianti (2017).
Bahwa semakin tinggi konsentrasi yang digunakan, maka kandungan senyawa metabolit sekundernya (alkaloid, saponin, fenolik, tritervenoid, flavonoid, dan glikosida) lebih banyak, sehingga daya racunnya semakin tinggi, dengan demikian kematian hama semakin cepat. Begitupun dengan perlakuan pestisida sintetik pada perlakuan p6 $(0,1 \%)$, semakin tinggi konsentrasi yang diberikan maka proses kematian PBKo akan semakin cepat, berbeda dengan kontrol kecepatan kematian PBKo sangat rendah. 


\section{SIMPULAN}

Berdasarkan hasil penelitian yang telah dilakukan maka dapat diambil kesimpulan sebagai berikut :

1. Pestisida nabati minyak kemiri sunan dapat mengendalikan hama penggerek buah kopi (PBKo)

2. Pada konsentrasi $8 \%$ minyak kemiri sunan sudah dapat mengendalikan hama penggerek buah kopi (PBKo) dengan persentase mortalitas $93 \%$, persentase intensitas serangan $2,5 \%$, dan persentase kecepatan kematian rata-rata 5,8 ekor/jam.

\section{DAFTAR PUSTAKA}

Direktorat Jendral Perkebunan 2014. Statistik Perkebunan Indonesia Kopi 2012-2014

Direktorat jendral perkebunan. Jakarta

Herman, M., Dibyo, P., Muhammad, S., Saefudin., dan Sumanto. 2013. Kemiri Sunan (Reutealis trisperma (Blanco) Airy Shaw) Tanaman Penghasil Minyak Nabati dan Konservasi Lahan . IAID Press, Jakarta

Irfan M. 2016. Uji Pestisida Nabati Terhadap Hama dan Penyakit Tanaman. Jurnal Agroteknologi. 6 (2) : 39-45.

Kaihena, M., V. Lalihatu, dan M. Nindatu. 2011. Efektivitas Ekstrak Etanl Daun Sirih (Piper battle L.) Terhadap Mortalitas Larva Nyamuk Anopheles $s p$ dan Culex. Jurnal Kedokteran dan Kesehatan Medica. 4 (1) : 88-105.

Kinasih, I. A. Supriatna dan R. N. Rusputra. 2013. Uji Toksisitas Ekstrak Daun Babadotan (Ageratum conyzoides Linn.) terhadap Ikan Mas ( Cyprinus carpio Linn.) sebagai Organisme Nontarget. Jurnal Biologi Fakultas Sains dan Teknologi UIN Sunan Gunung Djati Bandung ISSN. 7 (2) : 19798911.

Muta'ali. R., K. I. Purwani (2015). Pengaruh Ekstrak Daun Beluntas (Pluchea indica) terhadap Mortalitas dan Perkembangan larva Spodoptera litura $F$. Jurnal Sains dan Seni ITS 4 (2) : 5558

Pusat Penelitian dan Pengembangan Pertanian. 2012. Kemiri Suna. Http//: www. Puslitbang Perkebunan.go.id diakses pada 2 Maret 2019

Soesanthy, F., dan Samsudin. 2014. Pengaruh Beberapa Jenis Formula Insektisida nabati Untuk Melindungi Buah Kakao Dari Serangan Penggerek. Jurnal. TIDP. 1 (2): 69-78

Sonia, S., T. Siswancipto, dan T. Febrianti. 2017. Perbedaan konsentrasi dan jenis Pestisida Nabati terhadap Plutella xylostella pada Tanaman Kubis Ungu (Brassica oleraceae L.). JAGROS. ISSN. 1(2) : 2548-7752

Syafaruddin, S., T. J. Santoso 2011. Optimalisasi Teknik Isolasi dan Purifikkasi DNA yang Efisien dan Efektif pada Kemiri Sunan (Reutealis trisperma (Blanc) Airy Shaw). Jurnal Penelitian Tanaman Industri 17 (1) : 12

Wulanda, S., R. Aftiarani,. Z. K. Wardani.,N. Alfianto., I. Viki. 2017. Potensi Tanin Pada Ramuan Nginang Sebagai Insektisida Nabati Yang Ramah Lingkungan. Jurnal. Bioeksperimen. 3 (2) : 83-93 